\title{
Conventional tillage improves the storage of soil organic carbon in heavy fractions in the Loess Plateau, China
}

\author{
HAN Huige $^{1}$, LI Xudong ${ }^{1}$, NIU Decao ${ }^{1}$, Sharon J HALL ${ }^{2}$, GUO Ding ${ }^{1}$, WAN Changgui ${ }^{1,3}$, \\ Jennifer K LEARNED², FU Hua ${ }^{1 *}$ \\ ${ }^{1}$ State Key Laboratory of Grassland Agro-ecosystems, College of Pastoral Agriculture Science and Technology, Lanzhou \\ University, Lanzhou 730020, China; \\ ${ }^{2}$ School of Life Sciences, Arizona State University, Arizona 85281, USA; \\ ${ }^{3}$ Department of Natural Resources Management, Texas Technology University, Texas 79409, USA
}

\begin{abstract}
Soil labile organic carbon (C) plays an important role in improving soil quality. The relatively stable fractions of soil organic $\mathrm{C}$ (SOC) represent the bulk of SOC, and are also the primary determinant of the long-term $\mathrm{C}$ balance of terrestrial ecosystems. Different land use types can influence the distribution patterns of different SOC fractions. However, the underlying mechanisms are not well understood. In the present study, different fractions of SOC were determined in two land use types: a grazed grassland (established on previously cultivated cropland 25 years ago, GG) and a long-term cultivated millet cropland (MC). The results showed that $C$ concentration and $C$ storage of light fractions (LF) and heavy fractions (HF) presented different patterns along the soil profiles in the two sites. More plant residues in GG resulted in $91.9 \%$ higher LF storage at the $0-10 \mathrm{~cm}$ soil depth, further contributed to $21.9 \%$ higher SOC storage at this soil depth; SOC storage at $20-60 \mathrm{~cm}$ soil depth in MC was $98.8 \%$ higher than that in GG, which could be mainly attributed to the HF storage 104.5\% higher than in GG. This might be caused by the long-term application of organic manure, as well as the protection from plough pan and silt- and clay-sized particles. The study indicated that different soil management practices in this region can greatly influence the variations of different SOC fractions, while the conventional tillage can greatly improve the storage of SOC by increasing heavy fractions.
\end{abstract}

Keywords: land use; soil organic carbon; heavy fraction organic carbon; light fraction organic carbon; particle size distribution

Citation: HAN Huige, LI Xudong, NIU Decao, Sharon J HALL, GUO Ding, WAN Changgui, Jennifer K LEARNED, FU Hua. 2015. Conventional tillage improves the storage of soil organic carbon in heavy fractions in the Loess Plateau, China. Journal of Arid Land, 7(5): 636-643. doi: $10.1007 / \mathrm{s} 40333-015-0008-1$

Soil is the largest pool of terrestrial organic carbon, storing more carbon than that contained in the atmosphere and vegetation combined (Jobbagy and Jackson, 2000). It plays an important role in regulating the global carbon cycle. As land-use patterns change, soil may act either as a carbon source or a carbon sink. The organic $\mathrm{C}$ in the soil is not a uniform material (O'Hara et al., 2006) but rather a complex mixture of plant, animal and microbial residues in various stages of decomposition (Post and Kwon, 2000). The soil organic carbon (SOC) in light fraction (LF, with den- sity $<1.7 \mathrm{~g} / \mathrm{cm}^{3}$; LF organic carbon, LF-OC) is a component that commonly refers to relatively fresh, free or not well protected organic debris (Six et al., 2002; O'Hara et al., 2006) with high decomposability (Post and Kwon, 2000). In contrast, the SOC in heavy fraction (HF, with density $>1.7 \mathrm{~g} / \mathrm{cm}^{3}$; HF organic carbon, HF-OC) represents the comparatively decomposed component. HF-OC is clay- or silt-sized organo-mineral complexes (Post and Kwon, 2000). It is physically protected and not mineralized quickly (Whalen et al., 2000; Tan et al., 2007), and is thought

\footnotetext{
*Corresponding author: FU Hua (E-mail: fuhualzu@126.com)

The first and second authors contributed equally to this work.

Received 2014-11-04; revised 2015-05-04; accepted 2015-05-08

(C) Xinjiang Institute of Ecology and Geography, Chinese Academy of Sciences, Science Press and Springer-Verlag Berlin Heidelberg 2015
} 
to be the most abundant and recalcitrant form of SOC (Aanderud et al., 2010). The characteristics of LF and $\mathrm{HF}$ influence the mechanisms of SOC dynamics as related to land use and management.

It was reported that the grassland establishment on cropland can lead to the increase in SOC (Post and Kwon, 2000; Guo and Gifford, 2002; Paul et al., 2002; Wang et al., 2009; Don et al., 2011; Chen et al., 2012). The increase in SOC was mainly attributed to the increase of LF-OC (Robles and Burke, 1998; Christensen, 2000; Post and Kwon, 2000; Roscoe and Buurmanb, 2003; Wang et al., 2009; Liu et al., 2010). However, some researchers reported increased HF-OC (Post and Kwon, 2000; Yang et al., 2005; Wang et al., 2009) or unchanged HF-OC (Robles and Burke, 1998; Liu et al., 2010) following the conversion to grassland. The change in SOC after tillage breakage is influenced by the following factors and processes: (1) increased input of organic matter (OM) leading to higher LF-OC (Post and Kwon, 2000; Liu et al., 2010); (2) reduced decomposability of OM (Post and Kwon, 2000; Roscoe and Buurmanb, 2003); (3) enhanced physical protection either through intra-aggregates that increase LF-OC or through organo-mineral complexes that increase HF-OC (Post and Kwon, 2000; Roscoe and Buurmanb, 2003; Yang et al., 2005); and (4) decreased temperature, aeration and biological activity (Roscoe and Buurmanb, 2003) that increase LF-OC and decrease HF-OC (Cookson et al., 2005). However, previous studies on the effect of land use change on density fractions were mainly conducted in the surface soil, the effect on subsurface soil (below $20 \mathrm{~cm}$ depth) was rarely reported.

Land use in the Loess Plateau has undergone great changes in the past five decades (Li et al., 2013). Some researches indicated that grassland establishment on previously cultivated cropland increased LF dry matter, and consequently increased the storages of SOC in LF (Liu et al., 2010). But others reported that the re-established grassland had significantly lower SOC storages than cropland (Li et al., 2008a). These different responses might result from different sampling depths $(0-20 \mathrm{~cm}$ in Liu et al. (2010) and 0-100 cm in $\mathrm{Li}$ et al. (2008)). Li et al. (2008) neither investigate the processes underlying SOC responses to land-use type nor identify the SOC storages that may have high potential for soil carbon sequestration. Here, we investigated density fractions of SOC at 0-60 cm sampling depths under the same grassland and cropland settings as in Li et al. (2008a). Our objectives were to determine the mechanisms behind SOC storage responses to land-use type in the surface soil and subsurface soil. We hypothesized that conversion to grassland from cropland mainly causes a positive effect on LF-OC storages in the surface soil due to increased plant residues but a negative effect on HF-OC storages at a lower soil depth, thus leading to changes in mass distribution of SOC fractions.

\section{Materials and methods}

\subsection{Study area}

The study was conducted at the Semi-Arid Climate and Environment Observatory of Lanzhou University (SACOL) located in Gansu, China $\left(35^{\circ} 57^{\prime} \mathrm{N}, 104^{\circ} 09^{\prime} \mathrm{E}\right.$; $1,966 \mathrm{~m}$ asl). The region has a continental semi-arid climate with annual mean air temperature of $6.7^{\circ} \mathrm{C}$, a mean annual precipitation of about $382 \mathrm{~mm}$, and a short and concentrated rainy season (July to September) and long dry season. The soil is classified as a Calcisols (WRB Classification), a calcareous soil that is typical of the loess plateau. Substances, such as nitrogen (Zou et al., 2009) and clay, have seasonal leaching in this area. Two adjacent experimental sites (grazed grassland, GG; and millet cropland, MC) with an area of $2-\mathrm{hm}^{2}$ for each were selected for this study. These two sites were located at similar altitudes and slopes $\left(<5^{\circ} \mathrm{C}\right)$, shared a common bedrock, parent material (loess). The soil $\mathrm{pH}$ was 8.4 for the $\mathrm{GG}$ and 8.2 for the MC (Guo et al., 2013). GG site had been restored from cropping for 25 years and the dominant grass at the site was Stipa bungeana. The grazing intensity on this site was approximately $2.3 \mathrm{sheep} / \mathrm{hm}^{2}$. MC was planted with S. italica Beauv, and had been under conventional tillage for at least 55 years. Both organic manure and chemical fertilizer were applied to croplands annually. Organic manure $(3,000 \mathrm{~kg}$ dry matter $\left./ \mathrm{hm}^{2}\right)$, urea $\left(30 \mathrm{~kg} \mathrm{~N} / \mathrm{hm}^{2}\right)$ and calcium superphosphate $\left(60 \mathrm{~kg} \mathrm{P}_{2} \mathrm{O}_{5} / \mathrm{hm}^{2}\right)$ were applied manually prior to sowing in spring and incorporated in the soil by cultivation. The crop was harvested in October. 
The harvesting method in this region was different from that in other regions. Instead of cutting, the crop was harvested manually by pulling the plant from the soil, so aboveground tissue and most of the roots were removed from the soil and consequently small amount of residue retained in the soil.

\subsection{Soil sampling}

In August 2006, three replicated plots $(50 \mathrm{~m} \times 50 \mathrm{~m})$ were randomly chosen in each site, and two parallel $50 \mathrm{~m}$ transects $17 \mathrm{~m}$ apart within a plot were established. In May 2010 (after soil was tilled but not sown), five soil columns at five soil depth intervals $(0-10,10-20,20-30,30-40$ and $40-60 \mathrm{~cm})$ were collected along each $50 \mathrm{~m}$ transect at $10 \mathrm{~m}$ intervals using a soil probe $(6-\mathrm{cm}$ in diameter). The samples at the same depth from each transect were mixed as one composite sample. Soil bulk density (BD) was determined simultaneously using metal rings of known volume. Soil samples were then air-dried at room temperature, passed through a 2-mm sieve to remove coarse stones and large roots. Particle size distribution of these soil samples were analyzed by Mastersizer 2000 laser particle size analyzer.

\subsection{Density fractionation}

Soil samples were sorted by density into LF and HF following the modified procedure of Gregorich and Ellert (1993). The equivalents of $25 \mathrm{~g}$ of dry soil was weighed into a $100 \mathrm{~mL}$ pre-weighed plastic centrifuge tubes and $50 \mathrm{~mL}$ sodium iodide solution (density $=1.7 \mathrm{~g} / \mathrm{cm}^{3}$ ) was added to each tube. After gently shaking by hand for $30 \mathrm{~s}$, the tubes were shaken on a horizontal shaker for $1 \mathrm{~h}$, and then centrifuged at $1,000 \mathrm{~g}$ for $10 \mathrm{~min}$. The material floating on the sodium iodide solution (LF, specific gravity $<1.7 \mathrm{~g} / \mathrm{cm}^{3}$ ) was removed by suction on to a $0.45 \mu \mathrm{m}$ What-man filter paper and washed with $75 \mathrm{~mL}$ of $0.01 \mathrm{M} \mathrm{CaCl}_{2}$ to remove excess sodium iodide and rinsed with $75 \mathrm{~mL}$ distilled water, and then transferred to a pre-weighed $50 \mathrm{~mL}$ glass beaker. This process was repeated, and the combined LF material was combined with the previously collected one and allowed to settle overnight. The remaining HF was washed once with $0.01 \mathrm{M}$ $\mathrm{CaCl}_{2}$ and 3 times with distilled water. LF and HF were oven-dried $\left(65^{\circ} \mathrm{C}\right.$ for $\left.72 \mathrm{~h}\right)$, weighed, finely ground to pass a $0.25-\mathrm{mm}$ sieve and stored for analy- sis of organic $\mathrm{C}$ content.

\subsection{Carbon determination and data analysis}

Organic C concentrations of bulk soil and LF were analyzed by the oil bath- $\mathrm{K}_{2} \mathrm{CrO}_{7}$ titration method ( $\mathrm{Li}$ et al., 2010). LF-OC concentration was equal to the product of LF mass concentration and $\mathrm{C}$ concentrations in LF (C-LF) of bulk soil. HF-OC concentration was determined from the difference between total SOC concentration and LF-OC concentration. Organic $\mathrm{C}$ concentration in HF (C-HF) was the HF-OC concentration divided by the HF mass concentration of bulk soil.

SOC storage in soil was calculated for the $0-60 \mathrm{~cm}$ soil depths. SOC storage at each depth was determined as a product of BD $\left(\mathrm{Mg} / \mathrm{m}^{3}\right)$, SOC concentration $(\mathrm{kg} / \mathrm{Mg})$ and layer thickness $(\mathrm{T})(\mathrm{m})$ :

$$
\text { SOC } S_{i}=B D_{i} \times \text { SOC } C_{i} \times T_{i} \times 10000 \mathrm{~m}^{2} / \mathrm{hm}^{2} \times 0.001 \text {, }
$$

$$
\begin{gathered}
\text { LF-OC } S_{i}=B D_{i} \times \mathrm{LF}-\mathrm{OC} C_{i} \times T_{i} \times 10000 \mathrm{~m}^{2} / \mathrm{hm}^{2} \times \\
0.001, \\
\mathrm{HF}-\mathrm{OC} S_{i}=B D_{i} \times \mathrm{HF}-\mathrm{OC} C_{i} \times T_{i} \times 10000 \mathrm{~m}^{2} / \mathrm{hm}^{2} \times \\
0.001 .
\end{gathered}
$$

Where $i$ is the soil depth, $S_{i}$ is the storage at soil depth $i ; C_{i}$ is the relative organic $\mathrm{C}$ concentration of $i$ soil depth. The SOC storage was expressed as $\mathrm{Mg} / \mathrm{hm}^{2}$.

As the above method for calculating carbon storages do not fully account for variations in soil mass due to tillage activity in the cropland, the calculated data of carbon storages were further revised with the method mentioned by Ellert and Bettany (1995).

Statistical analysis was performed with the Windows-based Statistical Package for Social Sciences (SPSS, Inc., Chicago, IL, USA) program (ver.16.0). The SPSS program was used to determine the statistical significance between land use types and depth effects. Land use was considered as having main effect for the same sampling depth. A two-way ANOVA with depth and treatment as main effects respectively was performed to calculate the Fisher's LSD (least significant difference). Statistical significance was determined at $P<0.05$. Pearson linear correlations were used to evaluate relationships between the corresponding variables. 


\section{Results and discussion}

\subsection{Mass concentrations in light- and heavy-fractions of bulk soil}

Characteristics of density fractions associated with sampling depths are listed in Table 1. Mass distributions of different SOC fractions were influenced by management practices, with a lower mass concentration of LF at $0-10 \mathrm{~cm}$ soil depth in MC compared with GG. The result was consistent with Liu et al. (2010) who found that light fraction dry matter in surface soil was higher under native grassland than that under cropland. The LF originating from plant material is strongly affected by vegetation (Wang and Wang, 2011) and subsequently by litter inputs (Post and Kwon, 2000) in the surface soil. In this region, different harvesting methods left small amounts of residues to the soil. So, it is reasonable to assume that the higher LF concentration in the surface soil in GG can be attributed to the higher biomass input than that in MC ( $\mathrm{Li}$ et al., 2008). In addition, LF represents main soil active organic matter, which is altered not only by litter input but also by litter decomposition and erosion. In cropland, tillage activity can incorporate plant residues in the soil, and further increase soil temperature, aeration and biological activity, which may cause the decrease of LF (Roscoe and Buurman, 2003). Conversely, undisturbed soils usually offer a suboptimal decomposition environment (Guimarães et al., 2013), which could lead to the accumulation of LF in the surface soil in GG.

It showed no differences in mass concentrations of LF and HF between MC and GG at 10-20 cm depth. As there was a sharp decline of LF concentrations in GG with soil depths (from $12.13 \mathrm{~kg} / \mathrm{Mg}$ at $0-10 \mathrm{~cm}$ to $5.93 \mathrm{~kg} / \mathrm{Mg}$ at $10-20 \mathrm{~cm}$ depth), which was probably due to reduced litter input at $0-20 \mathrm{~cm}$ soil depth ( $\mathrm{Li}$ et al., 2008); However, there was only a slight variation with depths in MC soil $(6.68 \mathrm{~kg} / \mathrm{Mg}$ in $0-10 \mathrm{~cm}$ to $6.00 \mathrm{~kg} / \mathrm{Mg}$ at $10-20 \mathrm{~cm}$ depth), this might result from the application of manure and the mixing effect of plowing (Tan et al., 2007).

At $20-60 \mathrm{~cm}$ soil depths, MC had lower LF and higher HF mass concentrations than GG, and the differences were significant at $20-40 \mathrm{~cm}$ soil depths $(P<0.05)$. Compared with GG, the tillage effect on LF in $\mathrm{MC}$ was mainly at $0-20 \mathrm{~cm}$ soil depths which were above the plough pan (Don et al., 2011). So, LF in the subsoil was not significantly affected. The reason for the significantly higher LF at $20-40 \mathrm{~cm}$ soil depths in GG than that in MC might result from the significantly higher root biomass at $20-40 \mathrm{~cm}$ depths in GG, and the narrowed differences in root biomass between the two sites at $40-60 \mathrm{~cm}$ depths were found ( $\mathrm{Li}$ et al., 2008).

\subsection{Carbon concentrations in light- and heavy- fractions}

Significant treatment $(\mathrm{GG}$ and $\mathrm{MC})$ effects $(P<0.05)$ were also observed on both C-LF and C-HF (Table 1). At $0-30 \mathrm{~cm}$ soil depths, the C-LF in GG decreased

Table 1 Characteristics of density fractions of bulk soil

\begin{tabular}{|c|c|c|c|c|c|c|c|c|c|}
\hline \multirow{2}{*}{$\begin{array}{c}\text { Soil } \\
\text { depth } \\
(\mathrm{cm})\end{array}$} & \multirow{2}{*}{$\begin{array}{l}\text { Land } \\
\text { use }\end{array}$} & \multirow{2}{*}{$\begin{array}{l}\text { Bulk density } \\
\left(\mathrm{g} / \mathrm{cm}^{3}\right)\end{array}$} & \multicolumn{2}{|c|}{ Density fraction $(\mathrm{kg} / \mathrm{Mg})^{*}$} & \multirow{2}{*}{$\begin{array}{c}\text { C-LF } \\
(\mathrm{kg} / \mathrm{Mg})\end{array}$} & \multirow{2}{*}{$\begin{array}{c}\mathrm{C}-\mathrm{HF} \\
(\mathrm{kg} / \mathrm{Mg})\end{array}$} & \multicolumn{3}{|c|}{ Carbon concentration in bulk soil $(\mathrm{kg} / \mathrm{Mg})^{* *}$} \\
\hline & & & LF & $\mathrm{HF}$ & & & LF-OC & HF-OC & $\mathrm{SOC}$ \\
\hline \multirow[t]{2}{*}{$0-10$} & $\mathrm{MC}$ & $1.05 \pm 0.02^{\mathrm{e}}$ & $6.68 \pm 0.46^{\mathrm{b}}$ & $993.3 \pm 0.5^{\mathrm{d}}$ & $147.0 \pm 7.4^{\mathrm{a}}$ & $5.5 \pm 0.2^{\text {cd }}$ & $0.97 \pm 0.02^{b}$ & $5.49 \pm 0.20^{\text {cde }}$ & $6.47 \pm 0.19^{\text {bcd }}$ \\
\hline & GG & $1.29 \pm 0.00^{\mathrm{ab}}$ & $12.13 \pm 0.76^{\mathrm{a}}$ & $987.9 \pm 0.8^{\mathrm{f}}$ & $150.7 \pm 2.1^{\mathrm{a}}$ & $6.2 \pm 0.4^{\mathrm{cd}}$ & $1.83 \pm 0.11^{\mathrm{a}}$ & $6.06 \pm 0.38^{\mathrm{cd}}$ & $7.89 \pm 0.41^{\mathrm{ab}}$ \\
\hline \multirow[t]{2}{*}{$10-20$} & $\mathrm{MC}$ & $1.07 \pm 0.05^{\mathrm{e}}$ & $6.00 \pm 0.16^{\mathrm{b}}$ & $994.0 \pm 0.2^{\mathrm{d}}$ & $141.5 \pm 3.7^{\mathrm{a}}$ & $5.6 \pm 0.2^{\mathrm{cd}}$ & $0.84 \pm 0.04^{\mathrm{c}}$ & $5.54 \pm 0.22^{\mathrm{cd}}$ & $6.39 \pm 0.19^{\text {bcd }}$ \\
\hline & GG & $1.34 \pm 0.04^{\mathrm{a}}$ & $5.93 \pm 0.31^{\mathrm{b}}$ & $994.1 \pm 0.3^{\mathrm{d}}$ & $109.2 \pm 3.3^{\mathrm{bc}}$ & $5.3 \pm 0.6^{\text {cde }}$ & $0.64 \pm 0.02^{\mathrm{d}}$ & $5.25 \pm 0.57^{\text {cde }}$ & $5.90 \pm 0.59^{\text {bcd }}$ \\
\hline \multirow[t]{2}{*}{$20-30$} & $\mathrm{MC}$ & $1.14 \pm 0.02^{\mathrm{de}}$ & $3.01 \pm 0.13^{\mathrm{de}}$ & $997.6 \pm 0.1^{\mathrm{ab}}$ & $134.8 \pm 14.1^{\mathrm{ab}}$ & $8.5 \pm 0.5^{\mathrm{a}}$ & $0.40 \pm 0.03^{\mathrm{e}}$ & $8.44 \pm 0.47^{\mathrm{a}}$ & $8.84 \pm 0.46^{\mathrm{a}}$ \\
\hline & GG & $1.19 \pm 0.02^{\mathrm{cd}}$ & $4.67 \pm 0.17^{\mathrm{c}}$ & $995.3 \pm 0.2^{\mathrm{c}}$ & $62.7 \pm 4.0^{\mathrm{de}}$ & $4.8 \pm 0.8^{\mathrm{de}}$ & $0.29 \pm 0.01^{\mathrm{f}}$ & $4.81 \pm 0.84^{\mathrm{de}}$ & $5.10 \pm 0.85^{\mathrm{cde}}$ \\
\hline \multirow[t]{2}{*}{$30-40$} & $\mathrm{MC}$ & $1.16 \pm 0.01^{\mathrm{d}}$ & $2.42 \pm 0.14^{\mathrm{e}}$ & $997.6 \pm 0.1^{\mathrm{a}}$ & $83.4 \pm 6.4^{\mathrm{cd}}$ & $8.0 \pm 0.1^{\mathrm{ab}}$ & $0.20 \pm 0.01^{\mathrm{fg}}$ & $7.96 \pm 0.16^{\mathrm{ab}}$ & $8.16 \pm 0.19^{\mathrm{ab}}$ \\
\hline & GG & $1.22 \pm 0.01^{\mathrm{bcd}}$ & $3.74 \pm 0.21)^{\mathrm{cd}}$ & $996.3 \pm 0.2^{\mathrm{bc}}$ & $53.1 \pm 1.8^{\mathrm{e}}$ & $4.0 \pm 0.7^{\mathrm{ef}}$ & $0.20 \pm 0.01^{\mathrm{fg}}$ & $3.98 \pm 0.71^{\mathrm{ef}}$ & $4.18 \pm 0.71^{\mathrm{de}}$ \\
\hline \multirow[t]{2}{*}{$40-60$} & $\mathrm{MC}$ & $1.21 \pm 0.02^{\mathrm{bcd}}$ & $2.98 \pm 0.15^{\mathrm{de}}$ & $997.0 \pm 0.2^{\mathrm{ab}}$ & $48.4 \pm 9.3^{\mathrm{e}}$ & $6.6 \pm 0.3^{\mathrm{bc}}$ & $0.14 \pm 0.02^{\mathrm{g}}$ & $6.60 \pm 0.27^{\mathrm{bc}}$ & $6.75 \pm 0.29^{\mathrm{abc}}$ \\
\hline & GG & $1.26 \pm 0.02^{\mathrm{abc}}$ & $3.35 \pm 0.38^{\mathrm{de}}$ & $996.7 \pm 0.4^{\mathrm{ab}}$ & $58.4 \pm 1.4^{\mathrm{de}}$ & $3.1 \pm 0.3^{\mathrm{f}}$ & $0.19 \pm 0.02^{\mathrm{fg}}$ & $3.08 \pm 0.34^{\mathrm{f}}$ & $3.28 \pm 0.34^{\mathrm{e}}$ \\
\hline
\end{tabular}

Note: Means within each column followed with the same lowercase letter are not significantly different at $P<0.05$ level according to the LSD test. ${ }^{*}$ means the mass concentrations of density fraction of bulk soil. ${ }^{* *}$ means the concentrations of light fraction of soil organic carbon (LF-OC), heavy fraction of soil organic carbon (HF-OC) and soil organic carbon (SOC) in bulk soil. GG, grazed grassland; MC, millet cropland. 
sharply with sampling depths (from 150.7 to 62.7 $\mathrm{kg} / \mathrm{Mg}$ ), while no significant changes were observed in $\mathrm{MC}$ (from 147.0 to $134.8 \mathrm{~kg} / \mathrm{Mg}$ ). There were no significant differences in C-LF between treatments at 0-10 $\mathrm{cm}$ soil depth, but the values of C-LF at $10-40 \mathrm{~cm}$ soil depths were significantly greater for MC soil compared with GG $(P<0.05)$. It was reported that cellulose is preferentially utilized in the early stages of plant residue decomposition, so plant residue decomposition in soils proceeds initially through loss of $\mathrm{C}$ (Soon et al., 2009). In grassland, fresh root $C$ inputs and other organic residues are often accumulated at the soil surface (Yang et al., 2009); while in cropland, C-rich organic residues derived from manure (Römkens, 1999) and crops were plowed to a deeper soil depth (about $20 \mathrm{~cm}$ ) (Don et al., 2011), enhancing vertical transport of organic matter (even to an $80-\mathrm{cm}$ depth) (Römkens, 1999), which probably resulted in the higher C-LF in 10-40 cm soil depths in MC than that in GG .

Below 20-cm depths, C-LF in MC decreased sharply (from 134.8 to $48.4 \mathrm{~kg} / \mathrm{Mg}$ ), however, it showed little changes at 20-30, 30-40, 40-60 cm depths in GG (62.7, 53.1 and $58.4 \mathrm{~kg} / \mathrm{Mg}$, respectively). In $20-40 \mathrm{~cm}$ soil depths, significantly higher C-LF was observed in soils under MC than that under GG, which probably resulted from smaller amounts and differences of residue in subsoils than those in upper soils in GG (Li et al., 2008) and vertical transport of C from 20-30 cm soil depths (even to an 80-cm depth) caused by cropping (Römkens, 1999) and stronger leaching in MC than in GG.

$\mathrm{C}-\mathrm{HF}$ in GG decreased gradually with soil depths (from 6.2 to $3.1 \mathrm{~kg} / \mathrm{Mg}$ ) (Table 1). In contrast, the maximum $\mathrm{C}-\mathrm{HF}$ in $\mathrm{MC}$ was found at $20-30 \mathrm{~cm}$ soil depth $(8.5 \mathrm{~kg} / \mathrm{Mg})$, while those at $0-10$ and $10-20 \mathrm{~cm}$ soil depths were significantly lower (5.5 to $5.6 \mathrm{~kg} / \mathrm{Mg}$ ). These probably reflected the existence of a plough pan at about $20-\mathrm{cm}$ depth, where higher value of BD was found (Table 1), The plough pan can reduce the transportation of water and air, which might reduce HF decomposition and consequently increase C-HF in the deeper soils (Bertolino et al., 2010). From 20- to 60-cm depth, significantly higher C-HF was also observed in soil under $\mathrm{MC}$ than that under GG, which was likely attributed to the fact that the HF was origi- nated from plough pan.

In $\mathrm{MC}, \mathrm{C}-\mathrm{HF}$ showed a different trend from C-LF across soil depths, probably showing the greater tendency of HF to accumulate under the plough pan depth. In both two sites, C-HF showed greater differences than C-LF below $40-\mathrm{cm}$ depth, indicating that the plough pan may greatly contribute to the protection of HF in deeper soil depths. To better understand the underlying mechanism, further study with stable isotope method is required.

\subsection{Contribution of SOC in light- and heavy-fraction to total SOC storage}

SOC storage at $0-10 \mathrm{~cm}$ soil depth in GG was $21.9 \%$ higher than that in $\mathrm{MC}$, while $\mathrm{MC}$ contained $98.8 \%$ higher SOC storage than GG below $20 \mathrm{~cm}$ soil depth (Fig. 1c). The higher SOC storage at $0-10 \mathrm{~cm}$ soil depth under GG was attributed to higher LF-OC (91.9\% higher) and HF-OC (9.8\% higher) storages compared to that in MC (Figs. 1a and b), which resulted from significantly higher LF-OC concentration (59.9\% higher), higher HF-OC concentration (40.1\% higher) and higher BD (Table 1) under GG. Wind erosion may be one of the reasons causing the lower SOC storage at $0-10 \mathrm{~cm}$ soil depth under MC than that under GG. In contrast, soils in MC had $43.2 \%, 52.0 \%$ and $55.1 \%$ more HF-OC storages than those in GG at 20-30, 30-40, 40-60 cm soil depths, respectively, leading to higher SOC storages in MC in the corresponding soil depths. The results indicated that the increasing SOC storage at $0-10 \mathrm{~cm}$ depths following conversion from cropland to grassland was related to the increase of both LF-OC and HF-OC storages; whereas the higher SOC storages in the subsoil of MC was mainly attributed to higher HF-OC storages, which partly supported our hypothesis.

The SOC storage was predominantly associated with HF-OC storage, and the contribution of HF-OC to total SOC increased with soil depths, while that of LF-OC decreased with soil depths in both sites. The contribution of LF-OC to SOC ranged from $2.1 \%-14.7 \%$ at different soil depths in MC, which is included in the range (1\%-25\%) reported by Janzen et al. (1992). In contrast to MC, The contribution of LF-OC to SOC in GG $(4.7 \%-23.1 \%)$ was relatively greater except at $10-20 \mathrm{~cm}$ soil depth, a trend similar to non-disturbed alpine meadow in the Tibetan Plateau 

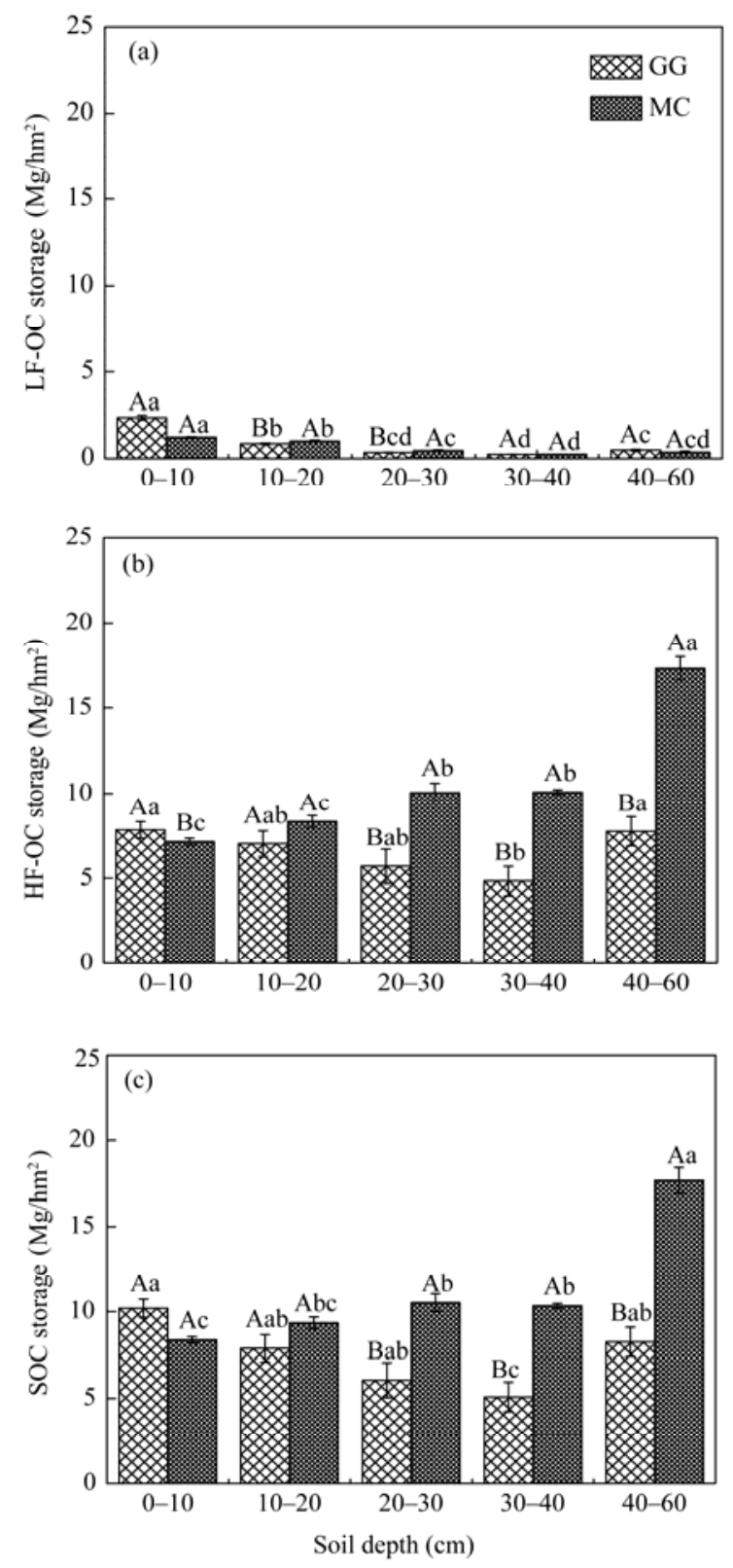

Fig. 1 Light fraction of organic carbon (LF-OC, a), heavy fraction of organic carbon (HF-OC, b) and soil organic carbon (SOC) storage (c) at each soil depth in grazed grassland (GG) and millet cropland $(\mathrm{MC})$. Different lowercase letters indicate significant differences at $P<0.05$ level among different soil depths in the same site; Different capital letters indicate significant differences at $P<0.05$ level between treatments at the same soil depth.

(Wang et al., 2009). The contribution of LF-OC to SOC in the top $10-\mathrm{cm}$ soil in GG site $(23.1 \%)$ was close to the value of $21.1 \%$ (Wang et al., 2009) and to that of sandy rangeland (25.5\%; Chen et al., 2012).

\subsection{Particle size distribution and its relationship with $\mathbf{H F}$}

Particle size distribution (PSD) along the soil profile varied between two sites (Table 2). The soil in MC had significantly higher silt and silt-clay and significantly lower sand content than that of GG, and the differences became obvious with the soil depths. This probably indicated that a shift in PSD was probably triggered by different land uses. This might be partially related to the reduced vegetation coverage due to grazing activity, which is consistent with the work of Elliott et al. (1991). Pei et al. (2008) also demonstrated that the pastures with long-term grazing resulted in $16 \%-26 \%$ higher coarse sand fraction and lower silt-clay fraction compared to the un-grazed pastures.

In GG, sand content increased gradually with soil depths, and the opposite trend occurred for silt-clay content, which coincided with the distribution of $\mathrm{C}-\mathrm{HF}$ and HF-OC. In MC, sand content decreased and silt-clay content increased from $10-20$ to $20-30 \mathrm{~cm}$ depths, and the minimum sand content (12.64\%) and maximum silt-clay content $(88.24 \%)$ occurred at 20-30 cm soil depths (where the plough pan located), where the highest values of $\mathrm{C}-\mathrm{HF}$ and $\mathrm{HF}-\mathrm{OC}$ were observed. For the two sites, both C-HF and HF-OC had highly negative correlation with sand contents, and highly positive correlation with silt-clay contents $(P<0.01$; Table 3$)$. Therefore, the higher values of $\mathrm{C}-\mathrm{HF}$ and HF-OC in the subsoil of MC could be probably attributed to higher silt-clay content than that in GG. These findings are in accordance with the results of Feller and Beare (1977) and Guggenberger et al. (1999) that clay- and silt-sized organo-mineral complexes (HF-OC) increased with increased silt-clay content. Compared with sand fraction, the silt- and clay-sized particles provide a larger surface area, numerous 'reaction spots' and strong bonding affinities to SOM (Lützow et al., 2007), thus are more capable of protecting the organic materials from decomposers, which aids the stabilization of organic $\mathrm{C}$. This indicated that the chemical or physio-chemical binding between SOM and soil minerals is one of the stabilization mechanisms of soil organic matter, which is defined as chemical stabilization by Six et al. (2002). 
Table 2 Particle size distribution along soil profiles of the two sites

\begin{tabular}{cccccc}
\hline $\begin{array}{c}\text { Soil depth } \\
(\mathrm{cm})\end{array}$ & Land use & \multicolumn{4}{c}{ Particle size distribution (\%) } \\
\cline { 3 - 5 } 0 & & Sand & Silt & Clay & Silt+Clay \\
\hline \multirow{2}{*}{$0-10$} & MC & $15.08 \pm 0.27^{\mathrm{f}}$ & $74.48 \pm 0.16^{\mathrm{bc}}$ & $10.26 \pm 0.26^{\mathrm{a}}$ & $84.75 \pm 0.32^{\mathrm{b}}$ \\
& GG & $16.45 \pm 0.14^{\mathrm{de}}$ & $73.36 \pm 0.08^{\mathrm{c}}$ & $10.15 \pm 0.21^{\mathrm{a}}$ & $83.52 \pm 0.14^{\mathrm{bc}}$ \\
\multirow{2}{*}{$10-20$} & MC & $15.38 \pm 0.47^{\text {ef }}$ & $74.29 \pm 0.10^{\mathrm{bc}}$ & $10.32 \pm 0.47^{\mathrm{a}}$ & $84.62 \pm 0.48^{\mathrm{b}}$ \\
& GG & $17.79 \pm 0.29^{\mathrm{c}}$ & $72.96 \pm 0.23^{\mathrm{c}}$ & $9.96 \pm 0.54^{\mathrm{a}}$ & $82.21 \pm 0.29^{\mathrm{c}}$ \\
\multirow{2}{*}{$20-30$} & MC & $12.64 \pm 0.02^{\mathrm{g}}$ & $77.73 \pm 1.42^{\mathrm{a}}$ & $10.52 \pm 0.51^{\mathrm{a}}$ & $88.24 \pm 1.37^{\mathrm{a}}$ \\
& GG & $17.15 \pm 0.06^{\mathrm{cd}}$ & $73.79 \pm 0.05^{\mathrm{bc}}$ & $9.39 \pm 0.31^{\mathrm{a}}$ & $83.18 \pm 0.29^{\mathrm{bc}}$ \\
$30-40$ & MC & $13.38 \pm 0.86^{\mathrm{g}}$ & $77.79 \pm 0.41^{\mathrm{a}}$ & $9.80 \pm 0.02^{\mathrm{a}}$ & $87.59 \pm 0.43^{\mathrm{a}}$ \\
& GG & $19.75 \pm 0.60^{\mathrm{b}}$ & $72.27 \pm 0.42^{\mathrm{c}}$ & $7.98 \pm 0.27^{\mathrm{b}}$ & $80.25 \pm 0.60^{\mathrm{d}}$ \\
& MC & $13.78 \pm 0.06^{\mathrm{g}}$ & $75.88 \pm 0.75^{\mathrm{ab}}$ & $10.69 \pm 0.43^{\mathrm{a}}$ & $86.57 \pm 0.36^{\mathrm{a}}$ \\
\hline
\end{tabular}

Note: Means within each column followed with the same lowercase letter are not significantly different at $P<0.05$ level according to the LSD test. GG, grazed grassland; MC, millet cropland.

Table 3 Correlations between density fractions of organic $\mathrm{C}$ and particle size distribution in the cropland and grassland

\begin{tabular}{cccccc}
\hline \multirow{2}{*}{ Parameter } & \multirow{2}{*}{ Land } & \multicolumn{4}{c}{ Particle size distribution } \\
\cline { 3 - 6 } & use & Sand & Silt & Clay & Silt+Clay \\
\hline \multirow{2}{*}{ HF-OC } & MC & $-0.686^{* *}$ & $0.820^{* *}$ & -0.280 & $0.686^{* *}$ \\
& GG & $-0.751^{* *}$ & 0.457 & $-0.767^{* *}$ & $0.751^{* *}$ \\
\multirow{2}{*}{ C-HF } & MC & $-0.685^{* *}$ & $0.819^{* *}$ & -0.288 & $0.685^{* *}$ \\
& GG & $-0.749^{* *}$ & 0.456 & $0.766^{* *}$ & $0.750^{* *}$ \\
\hline
\end{tabular}

Note: ${ }^{* *}$ means the significance at $P<0.01$ level. $n=20$. GG, grazed grassland; $\mathrm{MC}$, millet cropland.

In addition, chemical fertilizers and organic manure additions in MC may also provide stronger ligand exchange and polyvalent cation bridges (Lützow et al., 2007) to increase the C-HF and the amount of organo-mineral complexes (HF-OC) (Liang et al., 2012).

\section{Conclusions}

Twenty-five years after MC was converted to GG, a substantial SOC gain in the uppermost horizon soils was observed, which mainly resulted from the higher LF mass concentrations from more plant residues. In $\mathrm{MC}$, higher SOC storage in deeper soils was from the higher HF mass concentrations and $\mathrm{C}-\mathrm{HF}$, which can be partly contributed to the long-term application of organic manure. In addition, the plough pan, as well as the higher silt- and clay-sized particles played an important role in protecting the organic materials from decomposers, which improved the stabilization of organic C. This indicated that different soil management practices in this region can greatly influence the variations of different soil organic fractions, while the con- ventional tillage can improve soil organic carbon storage by the increase in heavy fraction.

\section{Acknowledgments}

This study was supported by National Basic Research Program of China (2014CB138703), the Strategic Priority Research Program of the Chinese Academy of Sciences (XDA05050403), Changjiang Scholars and Innovative Research Team in University (IRT13019), Key Science and Technology Projects of Gansu Province (1203FKDA035), Fundamental Research Funds for the Central Universities (lzujbky-2014-78) and the National Natural Science Foundation of China (31070412, 31201837). The authors are grateful to the Semi-Arid Climate and Environment Observatory of Lanzhou University (SACOL) for providing the meteorological data and supporting the field work. Thanks to ZHANG Chunping, AN Zhuo, YANG Yi and TENG Zeqin for their assistance in data collection.

\section{References}

Aanderud Z T, Richards J H, Svejcar T, et al. 2010. A shift in seasonal rainfall reduces soil organic carbon storage in a cold desert. Ecosystems, 13(5): 673-682.

Bertolino A V F A, Fernandes N F, Miranda J P L, et al. 2010. Effects of plough pan development on surface hydrology and on soil physical properties in Southeastern Brazilian plateau. Journal of Hydrology, 393(1): 94-104.

Chen Y P, Li Y, Zhao X, et al. 2012. Effects of grazing exclusion on soil properties and on ecosystem carbon and nitrogen storage in a sandy sange rangeland of Inner Mongolia, northern China. Journal of Environmental Management, 50(4): 622-632.

Christensen B T. 2000. Organic Matter in Soil-Structure, Function and Turnover. Tjele: DIAS Report No.30 Plant Production.

Cookson W R, Abaye D A, Marschner P, et al. 2005. The contribution of soil organic matter fractions to carbon and nitrogen mineralization and microbial community size and structure. Soil Biology \& Bio- 
chemistry, 37(9): 1726-1737.

Don A, Schumacher J, Freibauer A. 2011. Impact of tropical land-use change on soil organic carbon stocks-a meta-analysis. Global Change Biology, 17(4): 1658-1670.

Ellert B H, Bettany J R. 1995. Calculation of organic matter and nutrients stored in soils under contrasting management regimes. Canadian Journal of Soil Science, 75(4): 529-538.

Elliott E T, Palm C A, Reuss D E, et al. 1991. Organic matter contained in soil aggregates from a tropical chronosequence: correction for sand and light fraction. Agriculture Ecosystems \& Environment, 34(1-4): 443-451.

Feller C, Beare M H. 1997. Physical control of soil organic matter dynamics in the tropics. Geoderma, 79(1): 69-116.

Gregorich E G, Ellert B H. 1993. Light fraction and macroorganic matter in mineral soil. In: Carter M R, Gregorich E G. Soil Sampling and Method of Analysis. Boca Raton: Division of CRC Press, 397-407.

Guggenberger G, Frey S D, Six J, et al. 1999. Bacterial and fungal cell-wall residues in conventional and no-tillage agroecosystems. Soil Science Society of America Journal, 63(5): 1188-1198.

Guimarães D V, Gonzaga M I S, Silva T O D, et al. 2013. Soil organic matter pools and carbon fractions in soil under different land uses. Soil \& Tillage Research, 126: 177-182.

Guo L B, Gifford R M. 2002. Soil carbon stocks and land-use change: a meta analysis. Global Change Biology, 8(4): 345-360.

Janzen H H, Campbell C A, Brandt S A, et al. 1992. Light-fraction organic matter in soils from long term crop rotations. Soil Science Society of America Journal, 56(6): 1799-1806.

Jobbagy E G, Jackson R B. 2000. The vertical distribution of soil organic carbon and its relation to climate and vegetation. Ecological Applications, 10(2): 423-436.

Li X, Fu H, Li X, et al. 2008. Effects of land-use regimes on carbon sequestration in the Loess Plateau, northern China. New Zealand Journal of Agricultural Research, 51(1): 45-52.

Li X, Zhang C, Fu H, et al. 2013. Grazing exclusion alters soil microbial respiration, root respiration and the soil carbon balance in grasslands of the Loess Plateau, northern China. Soil Science and Plant Nutrition, 59(6): 877-887.

Liang Y, Han X Z, Ding X L, et al. 2012. Distribution of soil organic carbon and nitrogen in density fractions on black soil as affected by different amounts of organic manure application. Journal of Soil and Water Conservation, 26(1): 174-178. (in Chinese)

Liu X, Li F M, Liu D Q, et al. 2010. Soil organic carbon, carbon fractions and nutrients as affected by land use in semi-arid region of Loess Plateau of China. Pedosphere, 20(2): 146-152.

Lützow M V, Kögel-Knabner I, Ekschmitt K, et al. 2007. SOM fractionation methods: Relevance to functional pools and to stabilization mechanisms. Soil Biology \& Biochemistry, 39(9): 2183-2207.

O'Hara C P, Bauhus J, Smethurst P J. 2006. Role of light fraction soil organic matter in the phosphorus nutrition of Eucalyptus globulus seedlings. Plant and Soil, 280(1): 127-134.

Paul K I, Polglase P J, Nyakuengama J G, et al. 2002. Change in soil carbon following afforestation. Forest Ecology and Management, 168(1): 241-257.

Pei S, Fu H, Wan C. 2008. Changes in soil properties and vegetation following exclosure and grazing in degraded Alxa desert steppe of Inner Mongolia, China. Agriculture Ecosystems \& Environment, 124(1): 33-39.

Post W M, Kwon K C. 2000. Soil carbon sequestration and land-use change: processes and potential. Global Change Biology, 6(3): 317-328.

Robles M D, Burke I C. 1998. Soil organic matter recovery on conservation reserve program fields in Southeastern Wyoming. Soil Science Society of America Journal, 62(3): 725-730.

Römkens P F A M, Plicht J, Hassink J. 1999. Soil organic matter dynamics after the conversion of arable land to pasture. Biology and Fertility of Soils, 28(3): 277-284.

Roscoe R, Buurmanb P. 2003. Tillage effects on soil organic matter in density fractions of a Cerrado Oxisol. Soil \& Tillage Research, 70(2): 107-119.

Six J, Conant R T, Paul E A, et al. 2002. Stabilization mechanisms of soil organic matter: Implications for C-saturation of soils. Plant and Soil, 241(2): 155-176.

Soon Y K, Haq A, Arshad M A. 2009. Carbon and nitrogen contents of different-sized light fraction organic matter as influenced by tillage and residue management. Canadian Journal of Soil Science, 89(3): 281-286

Tan T, Lal R, Owens L, et al. 2007. Distribution of light and heavy fractions of soil organic carbon as related to land use and tillage practice. Soil \& Tillage Research, 92(1): 53-59.

Wang Q K, Wang S L. 2011. Response of labile soil organic matter to changes in forest vegetation in subtropical regions. Applied Soil Ecology, 47(3): 210-216.

Wang W Y, Wang Q J, Lu Z Y. 2009. Soil organic carbon and nitrogen content of density fractions and effect of meadow degradation to soil carbon and nitrogen of fractions in alpine Kobresia meadow. Science in China Series D: Earth Sciences, 52(2): 660-668.

Whalen J K, Bottomley P J, Myrold D D. 2000. Carbon and nitrogen mineralization from light- and heavy-fraction additions to soil. Soil Biology \& Biochemistry, 32(10): 1345-1352.

Yang Y S, Guo J F, Chen G S, et al. 2005. Carbon and nitrogen pools in Chinese fir and evergreen broadleaved forests and changes associated with felling and burning in mid-subtropical China. Forest Ecology and Management, 216(1): 216-226.

Yang Y S, Guo J F, Chen G S, et al. 2009. Effects of forest conversion on soil labile organic carbon fractions and aggregate stability in subtropical China. Plant and Soil, 323(1-2): 153-162.

Zou C, Xu F L, Yan Y D. 2009. Analysis of soil nitrogen leaching under different land uses patterns in the loess hilly and gully region. Journal of Soil and Water Conservation, 16(3): 114-116. (in Chinese) 